Albert L. Danielsen is Director of the James C. Bonbright Utilities Center and Professor Emeritus at the University of Georgia, Athens, Georgia. Dr. Danielsen, who holds a doctorate from Duke University, has specialized in market analysis and pricing, with publications that include The Evolution of OPEC in 1982 and Principles of Public Utility Rates in 1988 (with James C. Bonbright and

David R. Kamerschen). Except for a period between 1976 and 1978 when he was on leave with the U.S. Department of Energy, Dr. Danielsen has been at the University of Georgia since 1963.

Nainish K. Gupta is Experienced Manager in the utilities practice of Arthur Andersen Business Consulting, Atlanta. Before joining Andersen, he served as Director of Economic Analysis for the Retail Energy Services practice at Service Resources Inc., Marietta, Georgia. He holds a Ph.D. in economics from the University of Georgia's Terry College of Business.

Peter G. Klein is Assistant Professor of Economics at the Terry College of Business at the University of Georgia, Adjunct Scholar at the Mises Institute, and Associate Editor of The Collected

Works of F.A. Hayek (1989- ). His research focuses on law and economics, corporate finance, and the economics of organization. He holds a Ph.D. in economics from the University of California at Berkeley. The authors thank Paul Gentle for research assistance and Jerry Ellig, Robert Forry and Stephan Kinsella for helpful conversations. This paper draws on material in Breach of Contract in Electric Utilities: When Should Promises Be Broken? a mimeo distributed this year at the University of Georgia's Department of Economics.

\section{Contracts and the Institutional Environment for Electricity Reform}

Recent law and economics literature suggests that courts and administrative agencies should allow utilities to renegotiate supply contracts signed prior to restructuring, as an attractive alternative to continued regulatory oversight or possible bankruptcy.

\section{Albert L. Danielsen, Nainish K. Gupta, and Peter G. Klein}

$\mathrm{A}^{\mathrm{s}}$ electricity markets are restructured, buyers and sellers are increasingly relying on contracts to exchange energy and associated services. Unfortunately, many contracts currently in place were negotiated under more invasive regulatory regimes and are no longer economically viable. For instance, under the Public Utility Regulatory Policies Act of 1978 (PURPA), many utilities were required to buy power from qualifying facilities (QFs) at what regulators determined were their "avoided costs," the costs the regulators deemed the utilities would have incurred by producing the power themselves. Many such contracts were feasible only because regulation allowed utilities to recover costs from ratepayers under regulated tariffs. Furthermore, some utilities negotiated contracts with non-utility generators (NUGs) to honor obligations to serve native-load customers and signed take-or-pay agreements with price guarantees, believing that all costs would be recovered through tariffs paid by their ratepayers.

With the introduction of competition into electricity markets, captive ratepayers are being transformed into consumers with choices. Without their ability to pass costs on to ratepayers, utilities are finding it difficult to honor 
NUG contract obligations. Within the last five years, utilities such as Niagara Mohawk (NIMO) and Pennsylvania Power \& Light (PP\&L) have tried to renegotiate NUG contracts, leading to arbitration and litigation. Renegotiating NUG contracts remains an intensely political issue as state regulatory commissions and the Federal Energy Regulatory Commission (FERC) continue to be involved in the process. In several cases, these agencies have ruled that the original agreements remain in place.

Should the renegotiation of $\checkmark$ NUG contracts be permitted? The central issue is whether contracting parties have a legal duty to fulfill their obligations under all circumstances without modification, or whether under certain conditions, such as rapidly changing regulatory environments, contract renegotiations or even unilateral breach is preferable. In this article we draw on recent law and economics literature to argue that breach can, in some situations, be an efficient response to unforeseen changes in the legal, competitive, and regulatory environments. For this reason, the success of market-based reforms depends on how existing contracts are enforced and/or modified. Effective restructuring of the electric industry may require rethinking the legal arrangements designed under regulation. ${ }^{1}$

The way courts and administrative agencies treat contracts forms an important part of what Davis and North (1971) call the "institutional environment" in which con- tracts are designed. ${ }^{2}$ Studies of electric restructuring often overlook the role of the courts, but by establishing the "rules of the game" these institutions shape the feasibility and specific direction of reform. For instance, Glachant and Finon show that the structural differences among European electricity markets are explained largely by differences in legislative, judicial, and administrative proce-

The central issue is whether contracting parties have a legal duty to fulfill their obligations under all circumstances without modification.

dures in each country. ${ }^{3}$ They argue that the English-style disintegrated model has not been widely adopted on the Continent because those countries lack the stable, parliamentary, and largely unitary government that characterizes the United Kingdom. ${ }^{4}$ Similarly, electricity reform in the United States will be based on the legal status of contracts negotiated under previous regulatory regimes.

\section{Contracts and the Institutional Environment}

Before examining the particulars of NUG contracts, it is useful to review the modern economics literature on contracts and institutions, which is an important part of the "new institutional economics." ${ }^{5}$ Our treatment of institutions focuses on the branch of the new institutional economics that studies the "institutional environment." By Davis and North's definition, the institutional environment refers to the background constraints, or rules of the game, that guide the behavior of individuals and firms.

These can be both formal, explicit rules (constitutions, laws, property rights) and informal, often implicit rules (social conventions, norms). While the rules are the product of-and can be explained in terms of - the goals, beliefs, and choices of individual actors, the social result (the rule itself) is typically not known or "designed" by anyone. ${ }^{6}$

$\mathrm{D}$ avis and North distinguish the institutional environment from what they term "institutional arrangements." Institutional arrangements are specific guidelines-what Williamson calls "governance structures"7designed by trading partners to mediate particular economic relationships. Business firms, longterm contracts, public bureaucracies, nonprofit organizations, and other contractual agreements are examples of institutional arrangements. NUG contracts are thus particular institutional arrangements, while the contract law regime itself is part of the institutional environment.

The institutional environment forms the background against 
which institutional arrangements are designed. The content of particular contracts is circumscribed by the rules laid out in contract law, commercial codes, and other background rules. The new institutional economics has been particularly interested in contract law and property law. ${ }^{8}$ However, unlike the "legal centralism" tradition, which holds that disputes are primarily settled by the courts as official agents of the state, the new institutional economics focuses on private solutions, holding that "in many instances the participants can devise more satisfactory solutions to their disputes than can professionals constrained to apply general rules on the basis of limited knowledge of the dispute. ${ }^{\prime 9}$

Informal, and often tacit, rules are important not only for governing commercial relationships; they also structure other forms of social conduct. "[F]ormal rules . . make up a small ... part of the sum of constraints that shape choices; ... the governing structure is overwhelmingly defined by codes of conduct, norms of behavior, and conventions." ${ }^{10}$ Such rules, once established, form constraints for individual actors. Yet how can the rules themselves be explained in terms of purposeful individual choices? In Menger's words: "How can it be that institutions which serve the common welfare and are extremely significant for its development come into being without a common will directed toward establishing them?"11

Game theorists interpret informal institutions as Nash-equilibrium solutions to repeated games faced by individuals in social settings. ${ }^{12}$ These equilibria are described as "norms," "conventions," or "social institutions." As defined by Schotter, a social institution is "a regularity in social behavior that is agreed to by all members of society, specifies behavior in specific recurrent situations, and is either self-policed or policed by some external

\section{Informal, and often tacit,} rules are important not only for governing commercial relationships; they also structure other forms of social conduct.

authority."13 Ellickson explains that social norms can be superior to administrative or judicial dispute resolution among people with close social ties. ${ }^{14}$

However, such norms often develop within the formal legal framework. For example, law shapes the outcome of private bargaining by serving as a backup mechanism for resolving disputes that cannot be resolved privately. If the alternative to private dispute resolution is resolution in court, then the expected outcome at trial determines the parties' behavior during bargaining. Bargaining typically takes place "in the shadow of the law." ${ }^{15}$ Moreover, norms can help form the law, if judges look to social norms as guidelines for legal decisions. ${ }^{16}$ Today, many commercial disputes are resolved privately, through organizations such as the VISA Arbitration Committee. ${ }^{17}$ Still, private resolutions typically depend on the expected decisions of courts and regulatory bodies should parties fail to resolve their differences.

F or these reasons, court rulings contract renegotiations, and stranded-cost issues more generally, are extremely important. These rulings and decisions not only effect the specific parties to the dispute, they also help establish the legal framework within which future contractual negotiations will take place.

\section{Breach of Contract}

How should the legal system treat contractual breaches? Breaching a contract is breaking a promise, and for that reason alone many observers conclude that breach is necessarily immoral as well as illegal. However, contracts are breached routinely and are often renegotiated without litigation. Breach usually occurs when the cost of performing one's contractual obligations exceeds his expected liability for breach. If parties are liable only for actual damages imposed on their contractual partners, then breach will generally be efficient: I breach when the cost of performing to me exceeds the value of my performance to you. Such a breach is a (potential) 
Pareto improvement, saving resources that would otherwise be wasted fulfilling an economically nonviable agreement. ${ }^{18}$

1 fficient breaches are usually gation because they create potential gains that can be distributed among the contracting parties. Voluntary contractual renegotiations thus represent optimal breaches: no party is harmed by the change and at least one party is made better off. Litigating such disputes is usually more costly than private dispute resolution. Breaches that do not involve potential gains are more difficult to resolve privately because at least one party suffers net harm. For these reasons, efficient breaches are typically renegotiated privately, whereas inefficient breaches are more often resolved in court. This is the general pattern of dispute resolution in electricity markets.

A central question is whether and to what extent the legal remedies for breach are designed to promote optimal breach while discouraging non-optimal breach. When can releasing one party from an obligation benefit all parties? Courts typically employ one of three breach remedies: expectation damages (a payment that makes the victim of breach as well off as with performance), reliance damages (a payment that makes the victim as well off as if the contract had not been signed in the first place), and specific performance (court-ordered performance). The law and economics literature generally argues for an expectations damages rule to promote efficient investment and breach. A reliance damages rule creates a moralhazard problem that can lead to overinvestment by the potential victim of breach. Specific performance is usually imposed only in cases where there is no close substitute for the promised good (for example, a rare painting). Under expectation damages, however, the party that breaches bears the entire costs of breach, since the victim must be compensated for

\section{Efficient breaches are usually resolved without formal} litigation because they create potential gains that can be distributed.

investments made in anticipation of fulfillment. Breach will thus occur only if the net value of breach exceeds the net value of performance.

Formal recognition that damage remedies should be chosen to provide incentives for optimal breach as well as for performance is somewhat novel in the legal literature. But the damage rules that have in fact evolved, and especially expectation damages, provide appropriate incentives for both performance and optimal breach. Thus, while legal scholars and lawyers may argue that breach is immoral because it con- stitutes breaking a promise, the law and economics literature makes almost the opposite point. Since contracts are incomplete, breach may be exactly what the parties would have wanted, and would have specified, if the contract had been complete. ${ }^{19}$ Breach rules should thus be chosen according to the incentives they provide as well as the penalties they assess. Because damage awards establish the cost of certain behaviors, they should be regarded as prices as well as punishments.

\section{The Origin of NUG Contracts}

Most NUG contracts were negotiated after PURPA was passed in 1978. This law was enacted after four decades of market-demand prorationing of crude oil, after two decades of wellhead price regulation of natural gas, and five years after the Arab oil embargo in 197374. PURPA was designed primarily to conserve energy, reduce dependence on imported crude oil and refined petroleum products, and promote the use of renewable energy resources. One way these goals were to be achieved under PURPA was by encouraging and facilitating the development of cogeneration plants and smallscale, non-utility-owned qualifying facilities. Utilities were required to connect with these facilities and buy power at prices based on the avoided cost of the utilities' own additional power resources. When PURPA was conceived and implemented, most 
utilities believed that their next generating units would be traditional fossil-fuel boiler plants. Their experience with gas turbines in the 1960s and 1970s, regulatory moratoriums on the use of gas, and high gas prices precluded gas turbines from most generationexpansion plans.

7 he crowning blow was the

1 Fuel Use Act of 1977, which

precluded the use of natural gas as a fuel for new baseload units.

These factors combined to push utilities away from gas turbines until gas prices fell and the Fuel Use Act was effectively repealed in the mid-1980s. With metallurgical enhancements applied to gasturbine technologies, especially the improvements in the combinedcycle gas turbines, and lower gas prices, natural gas turbines became the technology of choice for new electric-generating units.

These developments were not anticipated in the early 1980s, when capital costs for nuclear and coal plants ranged from $\$ 1,000$ to $\$ 2,000$ per $\mathrm{kW}$, capital recovery was being deferred, and there were frequent generation plant cost overruns and escalating fuel costs. Under these circumstances the avoided costs were projected to be 5 to 9 cents per kWh, which was sufficient to adequately compensate many QFs for their investments and operating costs. Moreover, with the developments in natural gas technologies and prices noted above, natural-gas turbines became the technology of choice because they could be built for $\$ 600$ to $\$ 900$ per $\mathrm{kW}$ with fuel costs of 2.5 to 3.0 cents per $\mathrm{kWh}$.
The result was additional entry of NUGs that could produce and sell to incumbent utilities under power purchase agreements (PPAs) that contained very favorable terms. Moreover, under rateof-return regulation, a utility could pass through purchased power costs directly to its ratepayers while their own investments were increasingly subject to prudence review and management audit. The NUGs could take risks and

\section{In retrospect,} many states used avoided-cost estimates that turned out to be
much too high.

benefit from the expected price cost differentials, whereas the utilities could take risks but were required to pass the benefits on to their ratepayers. NUG agreements naturally flourished under these conditions. The PPAs often provided "must-run" status for QFs and NUGs to protect their investments, with little risk for the buyer as long as purchased power costs could be passed through. However, these provisions meant that the utility could not dispatch units in merit order, thereby resulting in utilities' cutting back on generating units with energy costs under 2 cents per $\mathrm{kWh}$ to operate the QF plants and/or pay contract prices of 5 to 9 cents per $\mathrm{kWh} .^{20}$

In retrospect, many states used avoided-cost estimates that turned out to be much too high. Oil-price forecasts in the early 1980s projected soaring fuel prices, with some analysts predicting crude oil prices of $\$ 100$ per bbl (\$17 per MMbtu) by 1985, and natural gas prices of $\$ 9$ per MMbtu. Some states incorporated escalation factors into NUG contracts based on these high fuel costs and inflation rates that had been experienced in the late 1970s and early 1980s. Because of the provisions in PURPA and the manner in which avoided-cost mandates were implemented by state commissions, some utilities were required to sign contracts for non-utility-generated power even when they did not need new capacity. In other instances far too much capacity was contracted for.

\section{DURPA incentives were origi- 1 nally expected to add some} $12,000 \mathrm{MW}$ of QF power by 1995 , but 32,000 MW of QF power had been developed by 1991. In California alone during 1984 and 1985, utilities signed contracts for thousands of megawatts of new capacity with prices based on wildly extravagant estimates of avoided costs. The projections were based on forecasts of rising fuel prices, with contract terms extending 15 to 20 years with fixed energy and capacity payments for the first 10 years. Although the expected high fuel prices never materialized, the utilities were required to pay avoided costs based on the fore- 
casts. These circumstances led to contracts that were prime candidates for breach and renegotiation. Efforts were made in the early 1990s to renegotiate the excessive avoided-cost payments, but since the QFs had based their investments on firm PPAs that had been authorized and encouraged under the requirements of PURPA, regulators and federal courts often defended the original contracts. ${ }^{21}$ Thus, QF contracts must be honored for the life of the contract or bought out prior to expiration.

NUG contracts are concentrated among only a few utilities, with two-thirds of all potentially stranded NUG contracts held by just 10 utilities. The top two account for more than 25 percent of the nation's entire stranded NUG contracts. ${ }^{22}$ As recently as 1995, NUGs supplied just 7 percent of all electricity to the grid, but represented one-third of the nation's potential stranded costs ( $\$ 42$ billion). ${ }^{23}$ The average price of NUG power was $\$ 62$ per MWh, or more than 70 percent higher than the cost of generation by utilities. Perhaps more troubling is the extremely long time horizon of the potential liabilities. If we analyze detailed information on more than 80 percent of all NUG contracts, we find only 29 percent of the contract commitments for a minimum of $200 \mathrm{GWh}$ a year expire before 2010 .

Utilities are paying more for power than ever before, as NUG purchases make up a large percentage of overall power purchases. These disparities have helped prompt some utilities to buy out their NUG contracts, risk bankruptcy, or press for regulatory reform and stranded-cost recovery. This is why the $\mathrm{QF}$ and NUG contracts are often part of a utility's stranded costs and as such represent an impediment to retail competition.

\section{Renegotiations of NUG Contracts}

As has been shown above, to date the most common utility and NUG relationship featured longterm PPAs for capacity and energy. Such PPAs made project financing of single assets feasible and attractive, especially when a creditworthy power purchaser, such as a cost-of-service regulated utility, was the counterparty to the PPA. Once in place, the PPA effectively insulated NUGs from competitive pressures. With wholesale electricity prices in the $\$ 27$ to $\$ 35$ per MWh range, it is not surprising that utilities with large numbers of NUG contracts are moving to reduce their exposure.

W $\mathbf{V}_{\text {term }}^{\text {hy did utilities sign long- }}$ first place? Why not simply rely on spot-market purchases to meet excess demands as needed, or on informal agreements for longerterm arrangements? The answer is simple: unlike implicit contracts or self-enforcing agreements, formal written contracts are legally enforceable. The buyers were willing to commit to long-term agreements because they had an obligation to serve, and their purchased power costs could be passed through to ratepayers. NUGs were willing to make commitments because the contracts contained pro-

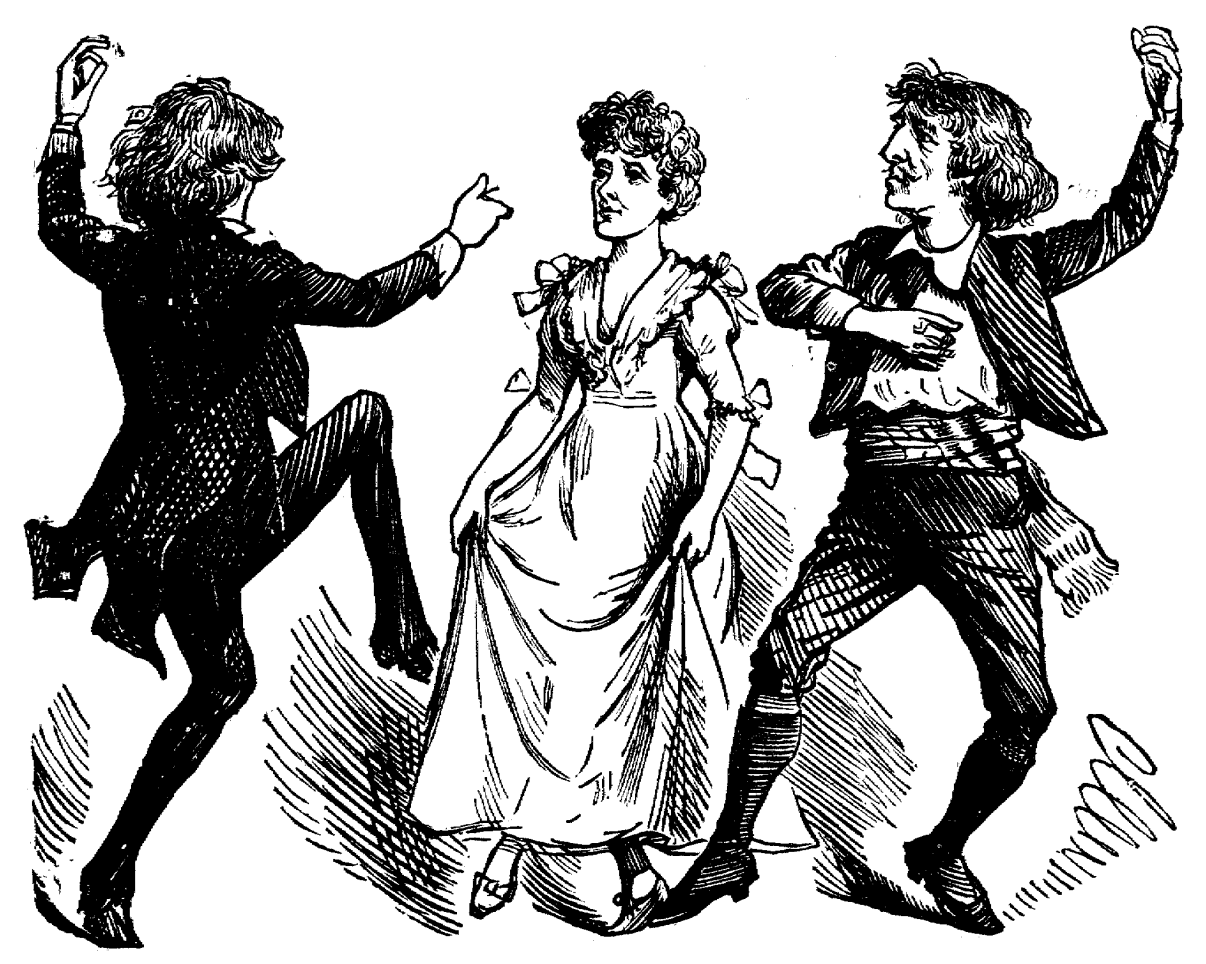

Once in place, the PPA effectively insulated NUGs from competitive pressures. 
visions that would allow them to cover costs and make a profit. The long-term power purchase agreements, unlike oral promises and atwill agreements, were backed by the power of the state. Legally binding written contracts enabled parties to cooperate by making their commitments credible.

$A_{\text {were signed, the possibility }}^{t \text { the time most NUG contracts }}$ of extensive regulatory restructuring and technological advancements were not sufficiently taken into account. However, the restructuring of natural gas markets along with advances in gas-turbine technology has revolutionized the generation business. A new combinedcycle gas plant can currently be built for approximately $\$ 400$ per $\mathrm{kW}$. Capital costs, operations and maintenance (O\&M) costs, and fuel costs can be recovered and still provide a profit margin at about 3 cents per $\mathrm{kWh}$ (assuming 95 percent capacity utilization).

This is cheap compared to the 5 to 9 cents per kWh paid under the earlier NUG contracts. At the moment, the high NUG costs are mostly recovered directly from electricity customers under costof-service regulation.

With the rising specter of competition, utilities are especially concerned with their exposure to NUG contracts that contribute to making their power among the most expensive in the United States. Market pressure and a deteriorating competitive position is forcing renegotiation of NUG contracts. The ability to lower the cost of purchased power may be problematic under many NUG con- tracts, since they are constrained by the terms of their financing agreements. With debt/equity ratios at $80 / 20$ at best, financial institutions have a lot of money at risk in PURPA-dependent plants. However, reductions in line with market rates are a much better alternative than bankruptcy, which some utilities may be forced to declare if these contracts are not renegotiated.

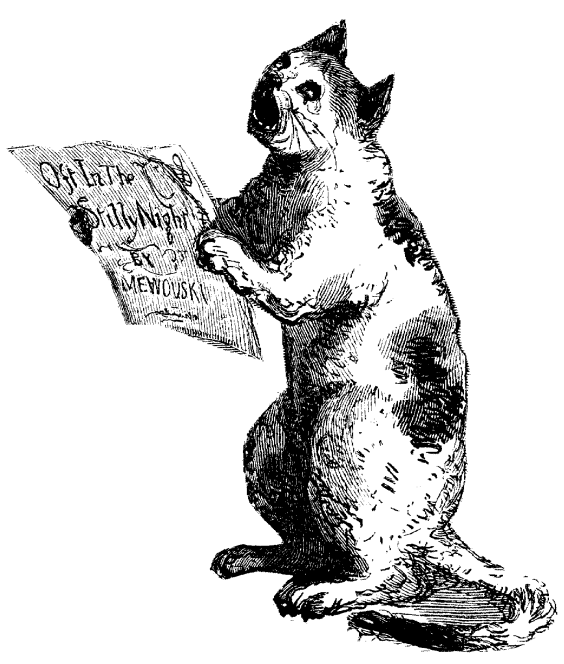

Electric companies have begun seeking solutions to the NUG problem. In March 1997, Niagara Mohawk Power Company (NiMo) and 19 NUGs announced that they had reached an agreement to restructure or terminate 44 power contracts. The present value of these 44 power contracts is approximately $\$ 9$ billion. According to NiMo, this agreement covers 90 percent of NiMo's above-market electricity costs, and it has been estimated that it will save NiMo $\$ 5$ billion over 15 years. The plan calls for the NUGs to receive $\$ 3.6$ billion in cash and equity of 46 million shares of NiMo stock.
$\mathrm{P}$ ennsylvania Power \& Light (PP\&L) also has moved to buy out NUG contracts. In early 1996, the company paid $\$ 91$ million to terminate a $100 \mathrm{MW}$ contract from a coal gasification plant. PP\&L still has a substantial exposure to NUG contracts that cost the company \$201.7 million in 1997 for 3,053 GWh of electric power. The average price of that power was $\$ 66.06$ per MWh with a range between $\$ 37$ per MWh and \$1,245 per MWh.

Third parties, such as Citizens Power, have successfully restructured some NUG contracts through a combination of physical and financial reengineering that maintained economic value for the NUG while generating substantial savings for the utility. In a recent restructuring of a contract between Central Maine Power (CMP) and Maine Energy Recovery Corporation, Citizens structured and implemented financing of over $\$ 80$ million, and accepted certain risks associated with this financing, in order to minimize the cost of the funds associated with the NUG. The flow of power supplied by the project was restructured, so that a lower level of power at abovemarket prices would flow to CMP from Citizens. The contract duration was extended five years, at a price consistent with market projections. Most importantly, the power pricing, formerly a single price per $\mathrm{kWh}$, was divided into an energy component and a capacity component to more accurately reflect costs under the restructured agreement. The sum of these new energy and capacity values reflects a significant saving (net present 
value: \$24 million) relative to the previous contract. $^{24}$

Clearly, these buyouts can generate gains for all parties, compared with the alternative of litigation or bankruptcy of the utility and/or NUG. Customers get part of the savings through lower prices as well. Hence, this kind of breach, followed by renegotiation, represents an efficient response to the changing environment facing electric utilities, and should not be discouraged by regulators or courts. Requiring utilities to honor the original NUG contracts represents specific performance, an inferior remedy to renegotiations that essentially provide breach victims with reliance or expectation damages.

When examining breaches, FERC and the courts should consider the relationship between the damage rule (and the compensation provided by renegotiations) and the recovery of stranded costs. For utilities, reliance damages exactly equal expectation damages under rate-ofreturn regulation; hence, utilities may be indifferent about which standard is used. For NUGs, expectation damages will generally exceed reliance damages by the expected net present value of their return on investment that is in excess of their cost of capital. This is generally presumed to be positive since the prices they received under PPAs were based on overstated estimates of avoided costs.

The ability to pass through the cost of purchased power in tariff rates under rate of return regulation made the NUG con- tracts reasonably acceptable to the utilities. But the advent of competition into wholesale and some retail electricity markets has made most of these contracts economically nonviable, since customers can buy power at market prices, leaving utilities saddled with the cost of NUG power. As the NUG contracts are renegotiated and possibly litigated the question arises as to what damage theory or

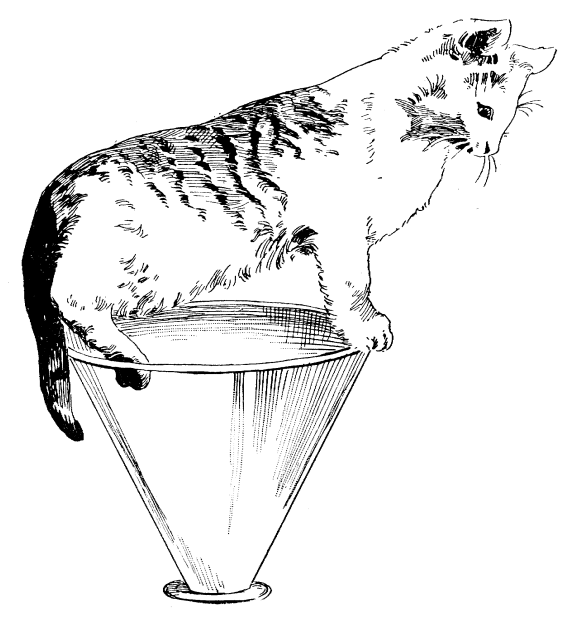

rule(s) should be applied. A reliance damages rule would compensate the NUGs for their sunk costs and would be equivalent to a merger or acquisition by the utility at historical costs. This would put NUG contracts on the same footing as the utilities' own investments under a cost-of-service regime. An expectation damages rule would compensate the NUGs for past investments in accord with their original expectations. A reliance damages rule may be a reasonable lower bound for negotiated or litigated settlements of NUG contracts with an expectation damages rule as the upper bound..$^{25}$

\section{Conclusion}

Clearly, as market governance replaces lighter forms of regulatory oversight, renegotiations and litigation over contractual terms will continue. The contracts utilities negotiated with NUGs when they were operating under rate-ofreturn regulation-with the expectation that purchased power costs would be passed through to their ratepayers-are prime examples. These contracts are often no longer viable as utilities face increasing pressure to lower costs to become competitive. One way to lower costs is to renegotiate NUG contracts, which we have argued can generate net gains.

More generally, private institutions and individuals operating within organizations and markets should be regarded as the first line of defense when dealing with contract breach. For contracts that are freely entered into, an expectation damages rule tends to promote optimal contract performance and optimal breach. Therefore, an expectation damages rule is appropriate when renegotiating or litigating such contracts. On the other hand, a reliance damages rule may be used as a lower bound when renegotiating or litigating contracts that were required or at least strongly influenced by more intrusive regulatory rules. These rules should help establish an institutional environment consistent with true structural reform.

1 ost importantly, contract allowed as an acceptable alternative to continued regulatory over- 
sight. Decisions about the restructuring of NUG contracts should be economically rather than politically motivated. Indeed, it was political motivation that gave birth to NUG contracts in the first place, and continued political intervention will only impede the progress of the electricity industry toward regulatory restructuring.

\section{Endnotes:}

1. We refer here to explicit contractual arrangements between utilities and NUGs. For applications of the breach literature to the general "regulatory compact" between utilities, regulators, and customers, see James Boyd, The "Regulatory Compact" and Implicit Contracts: Should Stranded Costs be Recoverable? 19(3) ENERgY J. 69-83 (1998), and J. Gregory SidaK and Daniel F. SPUlber, Deregulatory Takings and the ReguLATORY Contract (Sambridge University Press, 1998).
2. Lance E. Davis and Douglass C. North, Institutional Change AND American Economic Growth (Cambridge University Press, 1971).

3. JeAn-Michel Glachant and D. Finon, Why Do The European Union's Electricity Industries Continue To Differ? A New Institutional Analysis, in INSTITUTIONS, Contracts AND ORganizaTIONS: PERspectives from New INSTITUTIONAL Economics (Claude Menard, ed., Aldershott, U.K., Edward Elgar, forthcoming).

4. For a similar analysis of telecommunications reform, see BRIAN LEVY AND Pablo T. Spiller, EDS., Regulations, Institutions AND COMMITMENT: COMPARATIVe Studies of TelecommunicaTIONS (Cambridge University Press, 1996). For a more general treatment, see Mary M. Shirley, ED., Bureaucrats in Business: The Economics And Politics OF GOVERNMENT OWNERSHIP (Washington, DC, World Bank, 1995).

5. For a summary see EIRIK G. Furubotn AND Rudolf Richter, INSTITUTIONS

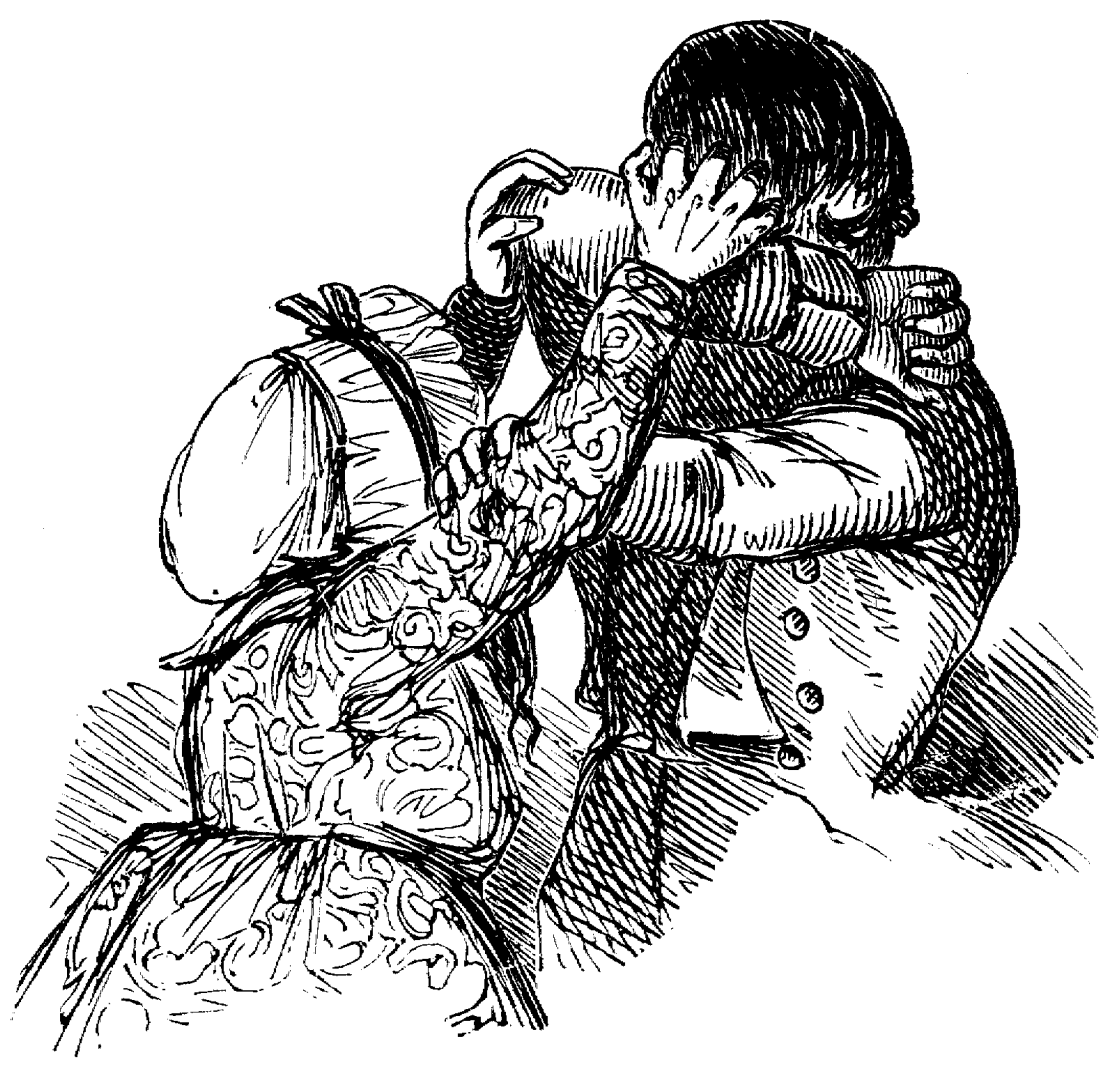

Continued intervention will only impede progress.
AND ECONOMic Theory: The CONTRIBUTION OF THE NeW INSTitutionAL ECONOMICs (Ann Arbor, Michigan, University of Michigan Press, 1997); and Peter G. KLEIN, New Institutional Economics, in ENCYCLOPEDIA OF LAW AND ECONOMICS (Boudewin Bouckeart and Gerrit De Geest, eds., Aldershott, U.K., Edward Elgar, forthcoming).

6. The social result is what Hayek would call a "spontaneous order," the result of a decentralized, invisible-hand process. See F.A. Hayek, The Results of Human Action but Not of Human Design, in idem., Studies in Philosophy, Politics, AND Economics (Chicago, University of Chicago Press, 1967); and F.A. HAYEK, LAw, Legislation, AND Liberty, Vol. 1, Rules and Order (Chicago, University of Chicago Press, 1973).

7. Oliver E. Williamson, The EcoNOMIC InSTITUTIONS OF CAPITALISM (New York, Free Press, 1985) and ThE Mechanisms of Governance (New York, Oxford University Press, 1996).

8. The literature focusing on contract law includes Karl N. Llewellyn, What Price Contract? An Essay in Perspective, 40 Yale L. REv. 704-51 (1931); Ian R. Macneil, The Many Futures of Contracts, 47 S. CAL. L. Rev. 691-816 (1974); Ian R. Macneil, Contracts: Adjustments of Long-Term Economic Relations under Classical, Neoclassical, and Relational Contract Law, 72 Nw. U. L. Rev. 854-906 (1978); and John H. Langbein, Comparative Civil Procedure and the Style of Complex Contracts, 35 Ам. J. Coмp. L. 381-94 (1987). The literature focusing on property law includes ARMEN A. Alchian, Some Economics of PropERTY (Santa Monica, CA, Rand Corp., 1961); Harold Demsetz, Toward a Theory of Property Rights, 57 AMERICAN ECONOMIC REV. 347-59 (1967); EIRIK G. Furubotn and Svetozar Pejovich, EDS., The Economics of Property Rights (Cambridge, Mass., Ballinger, 1974); Louis De Alessi, The Economics of Property Rights: A Review of the Evidence, in RESEARCH IN LAW AND ECONOMICS (1980): 1-47; and Yoram BARzel, ECOnOMic Analysis of Property Rights (Cambridge University Press, 1989).

9. Marc Galanter, Justice in Many Rooms: Courts, Private Ordering, and Indigenous 
Law, 19 J. of Legal Pluralism 4 (1981). Several recent studies on decentralized law and its evolution are examples of this "private ordering" tradition, among them Bruce L. Benson, The Enterprise of Law: Justice Without the State. (San Francisco, Pacific Research Institute for Public Policy, 1990); Robert C.

Ellickson, Order Without Law: How Neighbors Settle Disputes. (Cambridge, MA, Harvard University Press, 1991); and Robert D. Cooter, Structural Adjudication and the New Law Merchant: A Model of Decentralized Law, 14 INT'L REv. L. \& ECON. 215-31 (1994).

10. Douglass C. NoRTh, Institutions, Institutional Change AND ECONOMiC Performance (Cambridge University Press, 1990), at 36.

11. Carl Menger, Investigations into THE Method of the Social Sciences WITH SPECIAL REFERENCE TO ECONOMICS (New York, New York University Press, 1985; originally published in 1883), at 146.

12. An example is the coordination game made famous by Schelling (1960). Two friends arrange to meet one day at 5:00 p.m. in New York City. As the time of the meeting approaches, however, neither can remember where the meeting was to take place. Furthermore, the friends cannot contact each other to verify the location of the meeting; each must guess, independently, a likely meeting place. What can they do? This game has multiple Nash equilibria: any outcome in which both friends choose the same locationsay, the corner of 34th Street and 5th Avenue-is a Nash equilibrium to the game. According to Schelling, when faced with this kind of problem, agents rely on cultural information outside the structure of the game. Everyone simply knows, for example, that the logical place to meet in New York City is beneath the clock in the main terminal of Grand Central Station. This equilibrium is what Schelling called a "focal point." Over time, he argued, behavioral regularities develop so agents can solve these kinds of coordination problems. See Tномаs C. Schelling, The Strategy of Conflict (Cambridge, MA, Harvard University Press, 1960).

13. Andrew Schotter, The Economic Theory of Social Institutions (Cambridge University Press, 1981), at 11.
14. Ellickson, supra note 9.

15. Robert D. Cooter, S. Marks, and R. Mnookin, Bargaining in the Shadow of the Law: A Testable Model of Strategic Behavior, 11 J. Legal Studies 225-51 (1982).

16. The traditional account of the medieval law merchant illustrates this phenomenon. During the commercial revolution merchants developed a system of private courts to resolve disputes among themselves. The rules of these courts became general merchant practice, enforced by the threat of ostracism. As the English legal system developed, judges

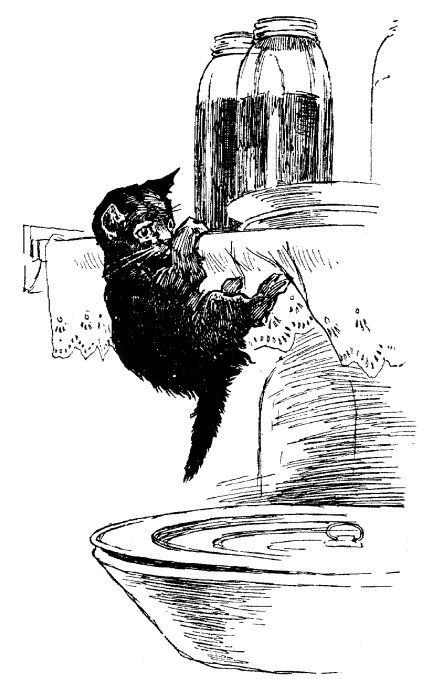

began to hear commercial disputes once handled privately. In resolving these disputes, English common-law judges tended to enforce the merchant customs already in place. In this way the common law came to embody the principles that already existed, principles developed through private interaction among merchants. On the law merchant, see LEON E. Trakman, The Law Merchant: The EvoLUTION OF COMMERCIAL LAW (Littleton, CO, Rothman \& Co., 1983), and Bruce L. Benson, The Spontaneous Evolution of Commercial Law, 55 S. Econ. J. 644-61 (1989).

17. Ronald L. Solove, Alternative Means to Resolve Corporate Disputes: A Survey, 91 Coм. L. J. 133-40 (1986), and Cooter, supra note 9.

18. For general discussions of the economics of contracts and breach, see RoBert D. Cooter and Thomas Ulen, LaW
AND Economics (Reading, MA, AddisonWesley, third ed., forthcoming in 2000); Steven Shavell, Contracts, and Aaron S. Edlin, Breach Remedies, both in Peter Newman, ed., The New Palgrave DicTIONARY OF ECONOMICS AND THE LAW (London, Macmillan, 1998).

19. Shavell, supra note 18 , at 11 .

20. Joseph Pokalsky and John Robinson, PURPA and Stranded Costs, in THE US Power MARKet: Restructuring AND Risk Management (London, Risk Publications, 1997).

21. See, for example, FERC decision EL95-41, denying a petition by Metropolitan Edison and Pennsylvania Electric to restructure six NUG contracts.

22. Southern California Edison and Pacific Gas \& Electric have the largest potentially stranded NUG contract exposure, and were No. 1 and 2 in the U.S. in 1997. SoCalEd's NUG total purchases cost $\$ 2.428$ billion in 1997 for some $27,000 \mathrm{GWh}$ at an average rate of $\$ 89$ / MWh. SoCal Ed derived 62 percent of all power purchases from NUGs in 1997, helping to give it the highest overall wholesale power cost in the country at \$76/MWh. PG\&E derived 49 percent of its power purchases from NUGs in 1997 and paid $\$ 1.595$ billion for 18,900 GWh, at an average rate of $\$ 84 / \mathrm{MWh}$. Source: RDI Energy Insight.

23. A total of $135,110 \mathrm{GWh}$ of power was purchased under the 150 highest-priced NUG contracts in 1997. Although down from $148,600 \mathrm{GWh}$ purchased in 1996, the total rate per megawatt hour was 12 percent higher. This contributed to a $\$ 180$ million increase in total electricity charges for NUG-produced power over 1996, making the total dollar expenditure $\$ 10$ billion. The same $\$ 10$ billion could have purchased some 300,000 GWh of electricity at an average price of $\$ 30 / \mathrm{MWh}$.

24. Larry Kellerman, The Management and Minimization of Stranded Generation Cost, in The US Power Market: RestructurING AND Risk Management (London, Risk Publications, 1997).

25. See the authors' mimeo, Breach of Contract in Electric Utilities: When Should Promises Be Broken? (University of Georgia Department of Economics, 1999) for a more complete exposition of these terms. 